\title{
The Inclusion of Acidic and Stormwater Flows in Concrete Sewer Corrosion Mitigation Studies
}

\author{
Georgios Fytianos ${ }^{1, * \mathbb{C}}$, Anastasios Tsikrikis ${ }^{2}$, Costas A. Anagnostopoulos ${ }^{3}$, Efthimios Papastergiadis ${ }^{1}$ and \\ Petros Samaras ${ }^{1}$ (D) \\ 1 Department of Food Science and Technology, International Hellenic University, 57400 Thessaloniki, Greece; \\ efspa@food.teithe.gr (E.P.); samaras@ihu.gr (P.S.) \\ 2 Department of Geology, Aristotle University of Thessaloniki, 54636 Thessaloniki, Greece; \\ tasostsik@gmail.com \\ 3 Department of Environmental Engineering, International Hellenic University, 57400 Thessaloniki, Greece; \\ kanagnos@cie.teithe.gr \\ * Correspondence: gfytianos@gmail.com; Tel.: +30-231-001-3355
}

Citation: Fytianos, G.; Tsikrikis, A.; Anagnostopoulos, C.A.; Papastergiadis, E.; Samaras, P. The Inclusion of Acidic and Stormwater Flows in Concrete Sewer Corrosion Mitigation Studies. Water 2021, 13, 261. https://doi.org/10.3390/ w13030261

Received: 27 December 2020

Accepted: 19 January 2021

Published: 22 January 2021

Publisher's Note: MDPI stays neutral with regard to jurisdictional claims in published maps and institutional affiliations.

Copyright: (c) 2021 by the authors. Licensee MDPI, Basel, Switzerland. This article is an open access article distributed under the terms and conditions of the Creative Commons Attribution (CC BY) license (https:// creativecommons.org/licenses/by/ $4.0 /)$.

\begin{abstract}
Concrete sewer pipes can be deteriorated by sulfuric acid $\left(\mathrm{H}_{2} \mathrm{SO}_{4}\right)$, which is created by the oxidation of hydrogen sulfide in the presence of certain bacteria inside the sewers. This process is called biocorrosion. In this paper, $\mathrm{H}_{2} \mathrm{SO}_{4}$ (i.e., chemical, non-biogenic) was used to study acid attack on concrete samples. The authors conducted experiments under different acid flows and concentrations, to account for the conditions prevailing in sewage networks exposed to flowing acidic waters. The effect of intermittent stormwater on the removal of protective layers was studied in addition to constant flow runs. Specimens' erosion depth was measured with a Vernier micrometer. In addition, unconfined compression at an axial strain rate of $0.0016 \mathrm{~mm} / \mathrm{mm} / \mathrm{min}$ was used for the estimation of unconfined compressive strength and elastic modulus. Moreover, the formation of gypsum as a protective layer and its role in biocorrosion was discussed. From this study, it was concluded that although the utilization of constant flowrates of acidic waters represents an important indication of corrosion mechanism, intermittent sewage and water flows should be taken into account, corresponding to real conditions in sewage networks, and resulting into accelerated concrete corrosion. Stormwater in combined sewers could remove the protective gypsum layer, thus accelerating chemical corrosion; however, in the presence of biogenic $\mathrm{H}_{2} \mathrm{SO}_{4}$, the removal of gypsum by excess flows due to stormwater could have a positive effect on corrosion mitigation. Finally, for combined sewers, selected coatings should withstand the effect of stormwater and high-velocity water flow tests should be included in future studies.
\end{abstract}

Keywords: concrete deterioration; wastewater corrosion; concrete sewers

\section{Introduction}

Sulfuric acid $\left(\mathrm{H}_{2} \mathrm{SO}_{4}\right)$ generated from microbiological activities can deteriorate concrete sewers, in a process called biocorrosion or microbiologically induced corrosion (MIC). The biogenic $\mathrm{H}_{2} \mathrm{SO}_{4}$ reacts with cementitious materials in concrete, resulting in structural failures of sewers [1,2]. Concrete is still one of the most widely used materials for sewer pipes worldwide, and due to the fact that replacement of concrete sewer pipes is difficult and costly, a sustainable coating application could play an important role in increasing the life expectancy of sewer systems. Concrete sewer system biocorrosion problems in Greece have been recently assessed [3], while an ongoing national R\&D project focuses on the development of an innovative active product, based on $\mathrm{Mg}(\mathrm{OH})_{2}$ and $\mathrm{MgO}$ [4], for the coating of the inner surfaces of concrete sewer network pipes to address corrosion problems [5,6]. However, prior to the implementation of coating practices, a corrosion study of concrete samples should take place, in order to study deterioration of concrete due to sulfuric acid. 
Generally, sulfate attack on concrete is not necessarily biogenic; when it comes to external sulfate attack, the reaction propagates from the surface toward the concrete core [7]. Biogenic corrosion inside concrete sewers is a specific context of sulfate attack.

Various researchers have studied concrete corrosion using chemical sulfuric acid [8-10] or biogenic sulfuric acid [11-13]. The biogenic $\mathrm{H}_{2} \mathrm{SO}_{4}$ corrosion mechanism is different compared to chemical $\mathrm{H}_{2} \mathrm{SO}_{4}$ attack [14]. The corrosion product in both cases is gypsum; in the case of chemical $\mathrm{H}_{2} \mathrm{SO}_{4}$, gypsum could act as a protective layer against further corrosion, while in the case of biogenic $\mathrm{H}_{2} \mathrm{SO}_{4}$, gypsum can be penetrated by bacteria. This protective layer on concrete surfaces due to the biocorrosion process consists of $\mathrm{CaSO}_{4}$ of various hydration states (gypsum) and moisture [11]. In a biocorrosion laboratory-scale experiment [11] on concrete coupons, the concrete corrosion process was accelerated when deteriorated materials were removed by sewage flow, as new surfaces were exposed. The reaction between gypsum and calcium aluminate in concrete can lead to the formation of ettringite, which contributes to concrete deterioration [15]. Recently, there were publications on the erosion of reinforced concrete walls by the flow of rainwater, and it was shown that it damaged the covers of the reinforcements and reduced their depth [16]. This study was not focused on concrete sewers, but rather on concrete structures. The development of green and sustainable coatings to mitigate biocorrosion in concrete sewers showed promising results [17]. In addition to pull-off tests for the coating adhesion properties, high-velocity water flushing can be used to mimic erosion due to stormwater in a combined sewer [6]. Corrosion of reinforcing steel and other embedded metals is the leading cause of deterioration in concrete [18].

In this paper, authors use the phrase "concrete corrosion" when referring to concrete deterioration due to sulfate attack, and "erosion corrosion" when acidic or water flows are involved in concrete corrosion. In this work, chemical sulfuric acid was used for the experimental tests. The tests were accelerated by means of increased acid concentration, in order to simulate future concrete deterioration. The current work is not intended to study numerous concentrations and flows, but rather to highlight the necessity of inclusion of acidic and water (especially stormwater) flows on the study of concrete deterioration.

In a combined network, variations in flow rates due to stormwater could occur. Most laboratory tests simply include immersion of concrete specimens into acidic solutions, but the authors conducted experiments under different sulfuric acid flows and concentrations due to the fact that real wastewater treatment facilities are exposed to flowing acidic water. Constant flow and intermittent flow were studied as well. The effects of static and flowing $\mathrm{H}_{2} \mathrm{SO}_{4}$ solutions in two different concentrations were examined. For the acidic solutions tests, the authors measured the specimens' erosion depth with a Vernier micrometer. In addition, the concrete specimens were tested under unconfined compression at an axial strain rate of $0.0016 \mathrm{~mm} / \mathrm{mm} / \mathrm{min}$, for the estimation of unconfined compressive strength and elastic modulus. The formation of gypsum as a protective layer and its role in biocorrosion was also discussed. Moreover, the effect of stormwater in the removal of the corrosive products and protective layer (i.e., gypsum) was examined. The time needed for gypsum to be removed after a sudden rainfall in a combined sewer network was examined as well.

\section{Materials and Methods}

A summary of the investigated sub-topics with the related experiments and sections is presented in Table 1. 
Table 1. Summary of experimental tests.

\begin{tabular}{ccc}
\hline Topic & Means of Investigation & Sections \\
\hline Concrete preparation & Mix composition presented in Table 2. & Section 2.1 \\
Gypsum formation & Immersion into $1 \mathrm{wt} \% \mathrm{H}_{2} \mathrm{SO}_{4}$ solution & Sections 2.2 and 3.1. \\
Gypsum removal & Application of water at a velocity of $7 \mathrm{~m} / \mathrm{s}$ & Sections 2.2 and 3.1. \\
Sulfur content on surface & Quantification with SEM-EDS & Sections 2.3 and 3.2. \\
Effect of flow on corrosion & Constant acidic flows with a velocity of $0.06 \mathrm{~m} / \mathrm{s}$ and & Sections 2.4 and 3.3. \\
Concrete mechanics & stormwater flows at a velocity of $7 \mathrm{~m} / \mathrm{s}$ & Sections 2.5 and 3.4. \\
\hline
\end{tabular}

Table 2. Concrete specimens mix composition.

\begin{tabular}{ccc}
\hline Material & Type & Composition \\
\hline Cement & CEM I 42.5 R & $410 \mathrm{~kg} / \mathrm{m}^{3}$ \\
Water & Tap water & $184.5 \mathrm{~kg} / \mathrm{m}^{3}$ \\
Limestone sand & $0-4 \mathrm{~mm}$ & $895 \mathrm{~kg} / \mathrm{m}^{3}$ \\
Limestone grit & $4-8 \mathrm{~mm}$ & $895 \mathrm{~kg} / \mathrm{m}^{3}$ \\
Plasticizer & SP Viscocrete & $0.5 \mathrm{wt} \%$ of cement \\
\hline
\end{tabular}

\subsection{Concrete Samples Preparation}

Concrete with a water/cement ratio of 0.45 , was chosen in order to represent the type of concrete used in Greek sewer concrete pipes. Sample composition is presented in Table 2. After mixing, the prepared concrete was poured into polyvinyl chloride (PVC) cylindrical molds $(30 \times 60 \mathrm{~mm})$. The components were mixed in a cement mixer, and the prepared concrete was poured into the plastic cylindrical molds. Immediately upon completion of casting, test specimens were transferred in a moist cabinet with a temperature of $23{ }^{\circ} \mathrm{C}$ and relative humidity of $95 \%$. After $24 \mathrm{~h}$ of curing, the specimens were de-molded and immersed in saturated limewater in a storage tank for 27 days at $20 \pm 2{ }^{\circ} \mathrm{C}$. The material properties of the concrete used, compressive strength and elastic modulus, were $39 \mathrm{MPa}$ and $32.85 \mathrm{GPa}$, respectively, after 28 days of curing.

\subsection{Microscopical Investigation on Gypsum Formation and Removal by Water Flow}

Certain specimens were half-length immersed into $1 \mathrm{wt} \% \mathrm{H}_{2} \mathrm{SO}_{4}$ solution in order to examine the formation of gypsum on a microscopic level. Samples were taken out of the $\mathrm{H}_{2} \mathrm{SO}_{4}$ solution weekly and were examined with a Carl Zeiss ${ }^{\mathrm{TM}}$ Stemi 2000-C Stereo microscope (Cambridge, UK).

Another set of concrete specimens (8 in total) was fully immersed in $10 \mathrm{wt} \% \mathrm{H}_{2} \mathrm{SO}_{4}$ solution for 1 week in order for gypsum to be formed. Then, high-velocity water (i.e., $v=7 \mathrm{~m} / \mathrm{s}$ ) was applied to samples that were covered with gypsum, in order to determine the time needed for gypsum to be removed completely. This time was used as the water flushing period in the case of intermittent stormwater described in Section 3.3. For comparison, it should be noted that the maximum velocity of transferred wastewater in cement pipelines does not usually exceed $3 \mathrm{~m} / \mathrm{s}$ [19].

\subsection{SEM-EDS for Sulfur Content on the Surface during Sulfate Attack}

Specimens immersed in sulfuric acid solution were tested via SEM-EDS to quantify the sulfur content on the concrete surface vs. time. Micrographs of concrete specimens were obtained using a Carl Zeiss EVO 50 VP scanning electron microscope (Carl Zeiss SMT, Ltd., Cambridge, UK). Examinations were performed at $10 \mathrm{kV}$ accelerating voltage, under variable pressure mode, suitable for nonconductive specimens, at a pressure of $30 \mathrm{~Pa}$. A variable pressure secondary electron (VPSE) detector was used. The elemental microanalysis was carried out by means of energy dispersive X-ray analysis (EDS), using a Bruker AXS Quantax 200 probe (Bruker, Madison, WI, USA) connected to the SEM 
apparatus, equipped with a Flash detector $40101(129 \mathrm{eV})$, operating under the same conditions as for imaging.

\subsection{Flowing Acidic Solution Experiments}

Cylindrical concrete specimens were immersed in acidic solutions inside a laboratorymade apparatus in order to examine the corrosion of concrete due to sulfuric acid. This device is shown in Figure 1 and was made by acrylic layers with dimensions length:width:height $=140: 30: 20 \mathrm{~cm}$. Vertical acrylic plates were placed inside the apparatus to receive three elongated pathways, allowing for the placement of 15 samples per row and the simultaneous examination of a total of 45 specimens. The apparatus content could be recirculated by an IWAKI magnetic drive pump under adjusted flowrates up to $30 \mathrm{~L} / \mathrm{min}$. Sulfuric acid solutions of 1 and $10 \%$ wt. were used for the examination of corrosion mechanism. In addition to acidic flow runs, static tests under stagnant sulfuric acid solutions were studied in an acrylic tank. The examination of constant flow rates was carried out continuously, consisting in the application of constant acid flows at certain concentrations, corresponding to a linear water velocity of $0.06 \mathrm{~m} / \mathrm{s}$. For the high-velocity stormwater intermittent test, flow rate corresponding to a linear velocity of $7 \mathrm{~m} / \mathrm{s}$ was applied twice per cycle for $15 \mathrm{~min}$ to account for conditions of increased flowrates due to stormwater in combined sewers.

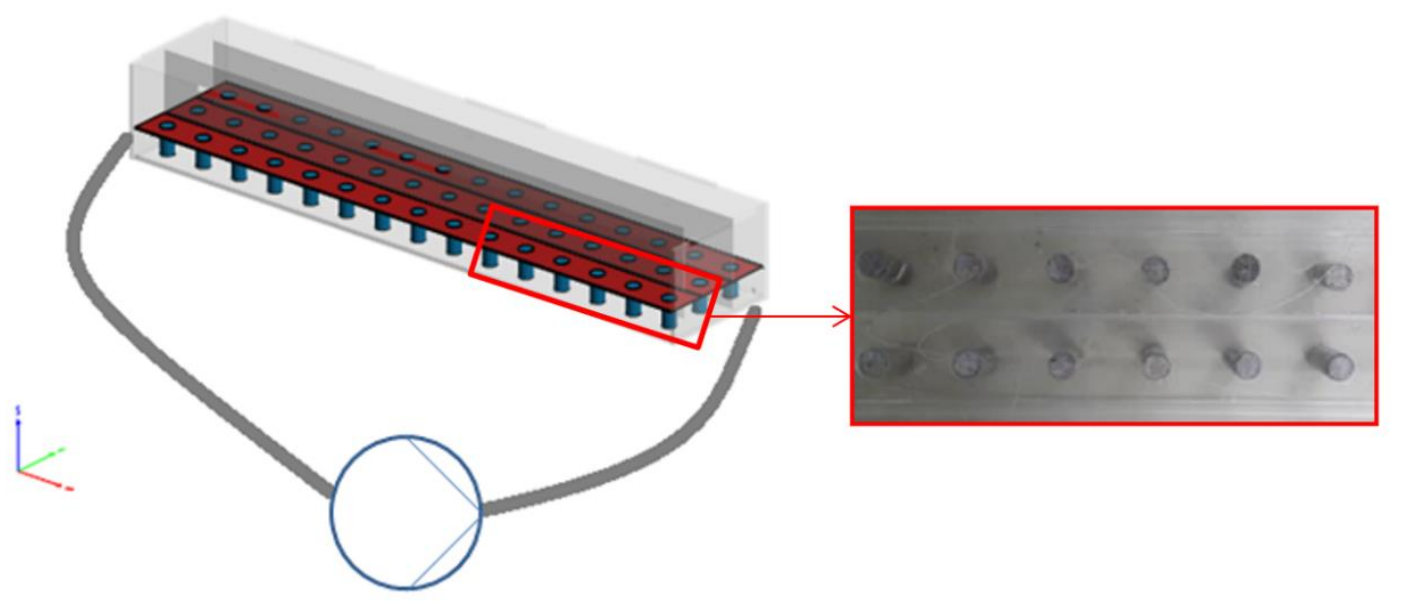

Figure 1. Experimental apparatus for concrete specimens' deterioration by $\mathrm{H}_{2} \mathrm{SO}_{4}$ solutions.

Specimens were withdrawn from the apparatus and subjected to further analysis for the estimation of erosion depth using a Vernier micrometer. The average value of three specimens, with a maximum allowable deviation of $5 \%$ from the average, is presented in Section 3.3.

\subsection{Unconfined Compressive Strength and Elastic Modulus}

Cylindrical specimens were tested under unconfined compression at an axial strain rate of $0.0016 \mathrm{~mm} / \mathrm{mm} / \mathrm{min}$ for the estimation of unconfined compressive strength and elastic modulus. An Instron servohydraulic (model $3500 \mathrm{KPX}$ ) compression testing machine was used, with a linearly variable differential transformer (LVDT), and load cell linked to a data-logging computer to record the compressive stress-strain during the test. The elastic modulus was determined from the linear part of the stress-strain plot according to ASTM C469-10 [20]. Each of the reported compressive strength and elastic modulus values is taken as the average value of at least three measurements, with a maximum allowable deviation of $5 \%$ from the average. 


\section{Results}

\subsection{Gypsum Formation on Concrete and Its Removal by Liquid Flows}

In Figure 2, gypsum formation on specimens partially immersed in $1 \% \mathrm{H}_{2} \mathrm{SO}_{4}$ solution, under static conditions, can be observed after 1,3,4, and 5 weeks of immersion. During the first week, gypsum in the form of crystals is formed, which over time are gradually expanded and transformed to larger aggregates. During the last weeks of the experiment, aggregates form a denser and more compact layer covering almost the whole surface of the specimen. The gypsum layer thickness was from 0.2 to $0.6 \mathrm{~mm}$.
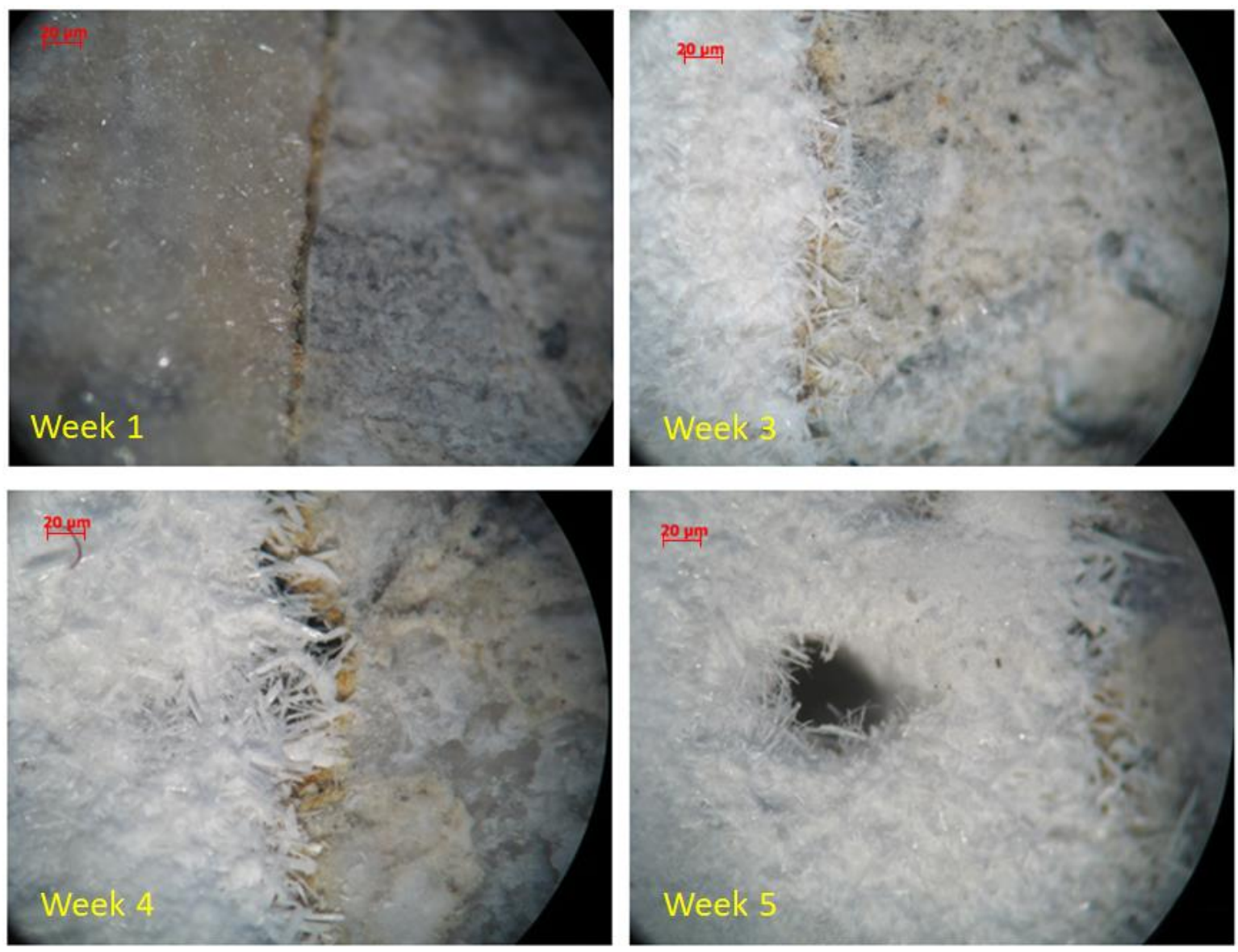

Figure 2. Gypsum formation on concrete specimen vs. time (1, 3, 4, 5 weeks).

Application of short-time high water flow on specimen surfaces that were exposed to high-velocity water flowrates (i.e., $v=7 \mathrm{~m} / \mathrm{s}$ ) - simulating the introduction of stormwater in combined sewage networks-resulted in partial removal of the protective gypsum layer after $10 \mathrm{~min}$, while almost complete removal was observed after $20 \mathrm{~min}$ as shown in Figure 3. Both microscopical and optical examination indicated that the gypsum layer was removed. However, no XRD analysis took place. Moreover, macroscopically, a gypsum layer has a characteristic white cover around concrete specimens, and after $20 \mathrm{~min}$, this cover seemed to be completely removed. No other change was visible after $20 \mathrm{~min}$. One pair of concrete specimens was used for each time test (a total of 8 specimens). Therefore, it can be concluded that increased flowrates in combined networks due to sudden heavy rain results in the removal of protective gypsum layers from the surface of concrete pipes. 

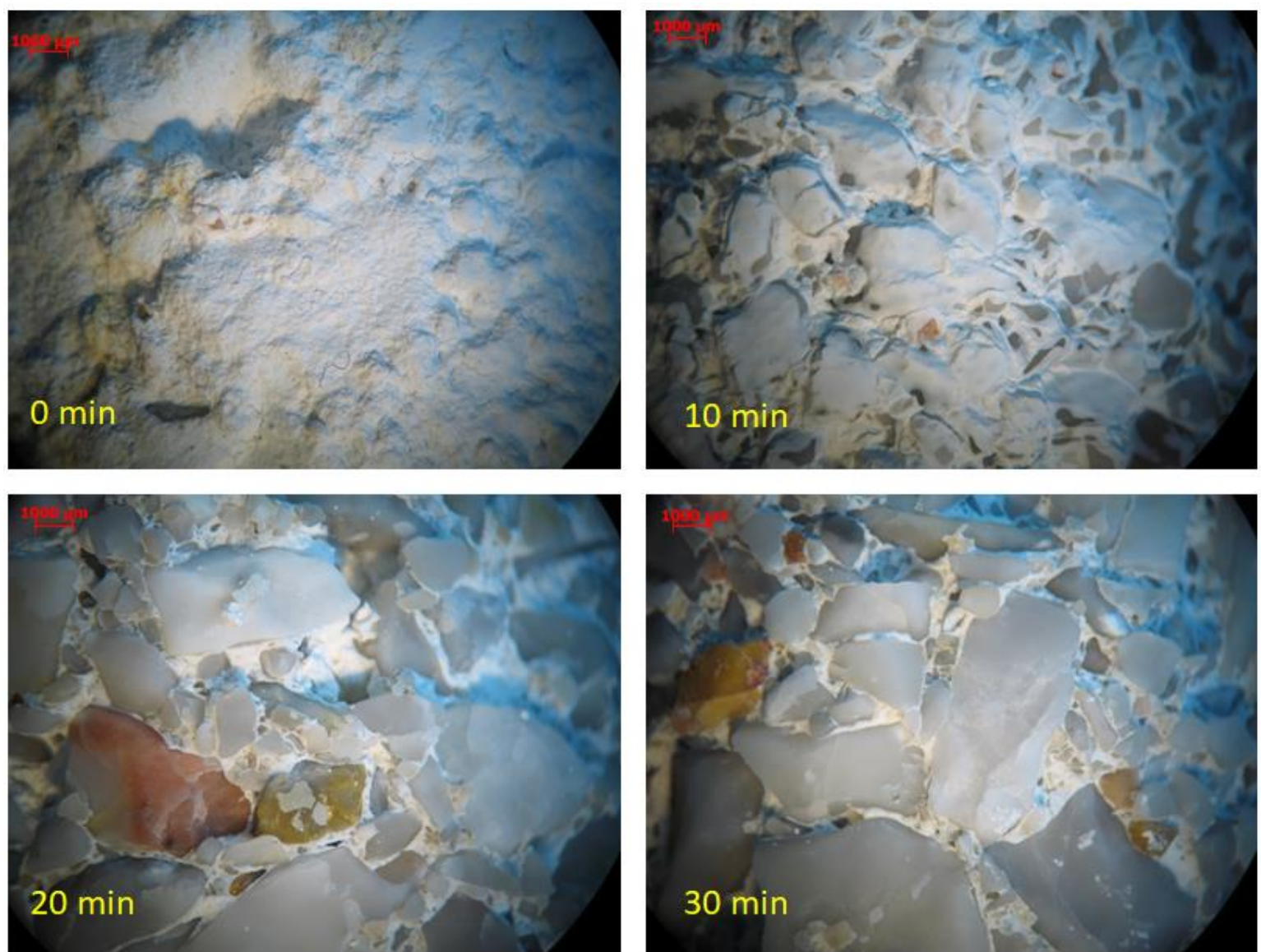

Figure 3. Gypsum removal with high-velocity water vs. time (After 0, 10, 20, and $30 \mathrm{~min}$ ).

\subsection{Sulfur Content on the Concrete Surface during Sulfate Attack}

Sulfur content on the surface of the specimens increased over time as shown in Figure 4, where the gypsum layer formation could act as a protective layer which allows reactions between cement and sulfuric acid to occur mainly on the concrete surface. After 1 week, sulfur was detected on the specimens' surface. After 3 weeks in $\mathrm{H}_{2} \mathrm{SO}_{4}$ solution, gypsum layers were formed (as is also shown in Figure 2) and that is why Figure 4 shows a minor increase in sulfur content on the concrete surface (due to gypsum formation). The rate of increase seemed to drop during the last weeks, indicating the formation of gypsum layers.

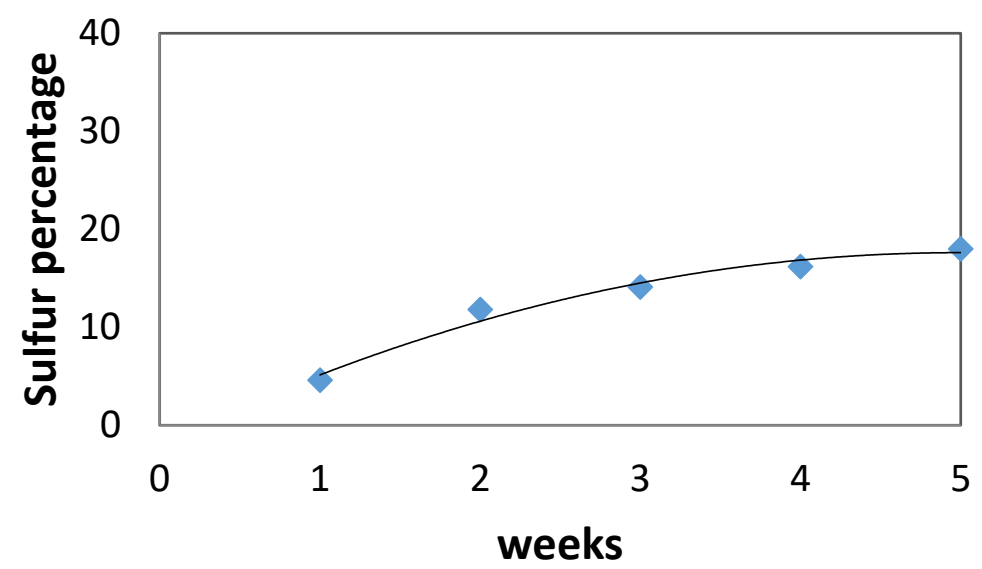

Figure 4. Sulfur \% onto concrete surface vs. time. 
Examples of SEM micrographs, including EDS elemental analysis, are given for specimens that were subjected to immersion into static $\mathrm{H}_{2} \mathrm{SO}_{4}$ solutions for 1 and 5 weeks respectively (Figure 5). After 1 week, elemental mapping showed sulfur content, while in week 5 , sulfur covered most of the surface.
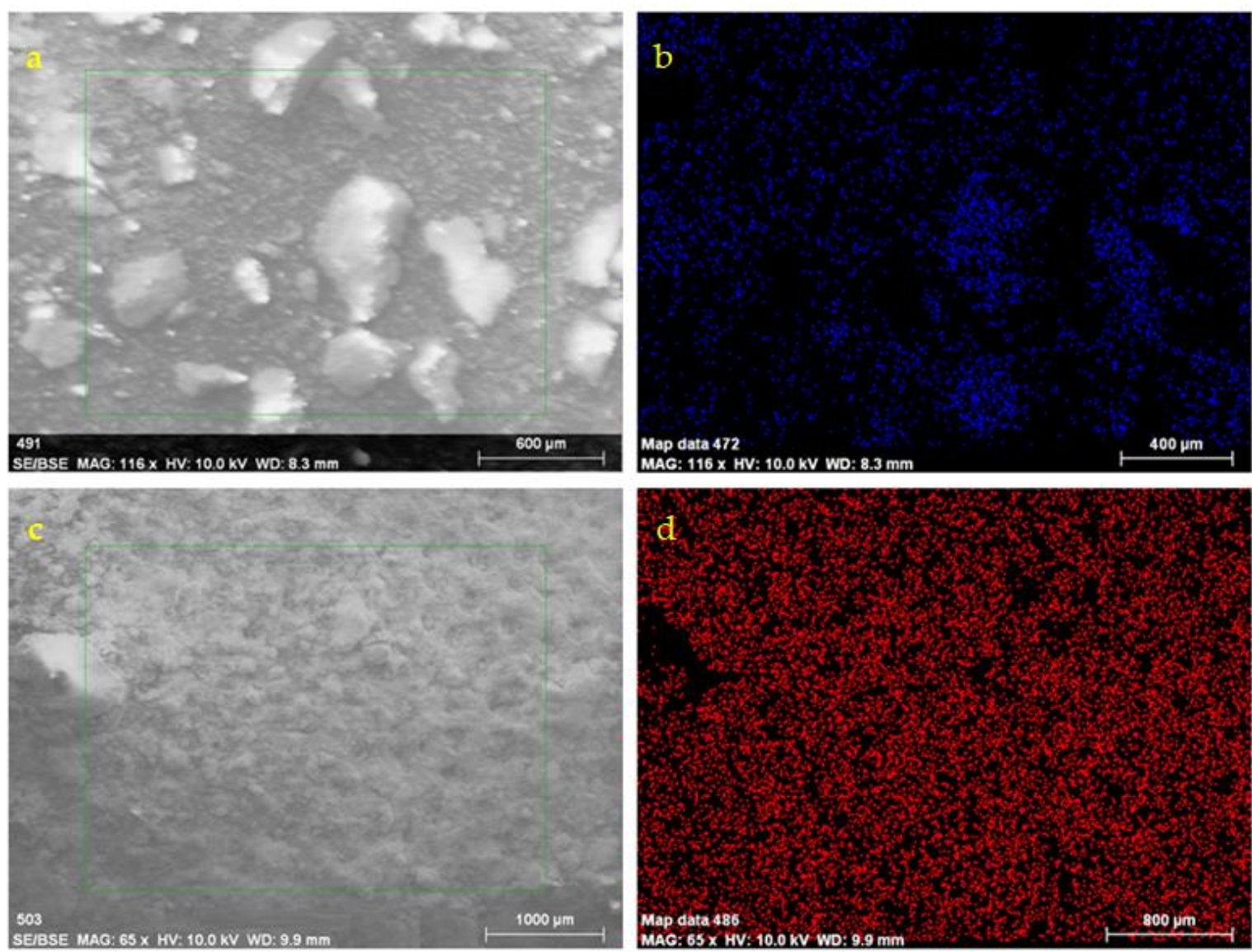

Figure 5. SEM-EDS for concrete specimens subjected to immersion into static $\mathrm{H}_{2} \mathrm{SO}_{4}$ solutions for 1 (a,b) and 5 (c,d) weeks, respectively. (b) and (d) are the $\mathrm{S}$ elemental maps for (a) and (c) SEM images, respectively.

\subsection{Effect of Flow and Concentration}

The erosion depth of concrete specimens as a function of time is shown in Figure 6, under static, constant, and intermittent flow modes of operation. Positive values on the y axis indicate a decrease in samples' diameter due to corrosion, while negative values on the y axis show expansion of samples' diameter. From this figure, it can be observed that the concentration of the acidic solution represents a significant corrosion parameter, since higher erosion depths are observed under higher concentrations at a given time. Nevertheless, at higher concentrations, the erosion rate was increased by the flow, attributed to the removal of the protective layer of gypsum under the application of high shear forces. These results are in agreement with the results of [9] who observed that in concrete corrosion caused by $\mathrm{H}_{2} \mathrm{SO}_{4}$, the fluid flow accelerates the deterioration. In the case of $1 \%$ acid solution, solid conclusions cannot be drawn regarding the effect of flow rate on the erosion mechanism. In addition, under that concentration, samples seemed to expand, initially due to gypsum formation. After 1 week of immersion in the acidic solution, the formation of gypsum led to a slight increase in the specimens' volume. At a second stage, after a long period exceeding 3 months, the corrosion depth increased at an observable rate; these results are in accordance with similar reports [9]. However, at higher acidic concentrations, the time period for increase in corrosion depth was reduced to one week. Intermittent flow modes resulted in an even higher erosion depth increase, 
even over short time periods; concrete specimens' corrosion depth exceeded $20 \mathrm{~mm}$ after 7 weeks of operation, while a similar depth was not measured under high flowrate or static conditions, even after 12 weeks of operation. This behavior is attributed to frequent gypsum protective layer removal over a short time by high-velocity water flushing. After 8 weeks of intermittent stormwater flow, the concrete specimens were almost completely deteriorated and the experiment stopped.

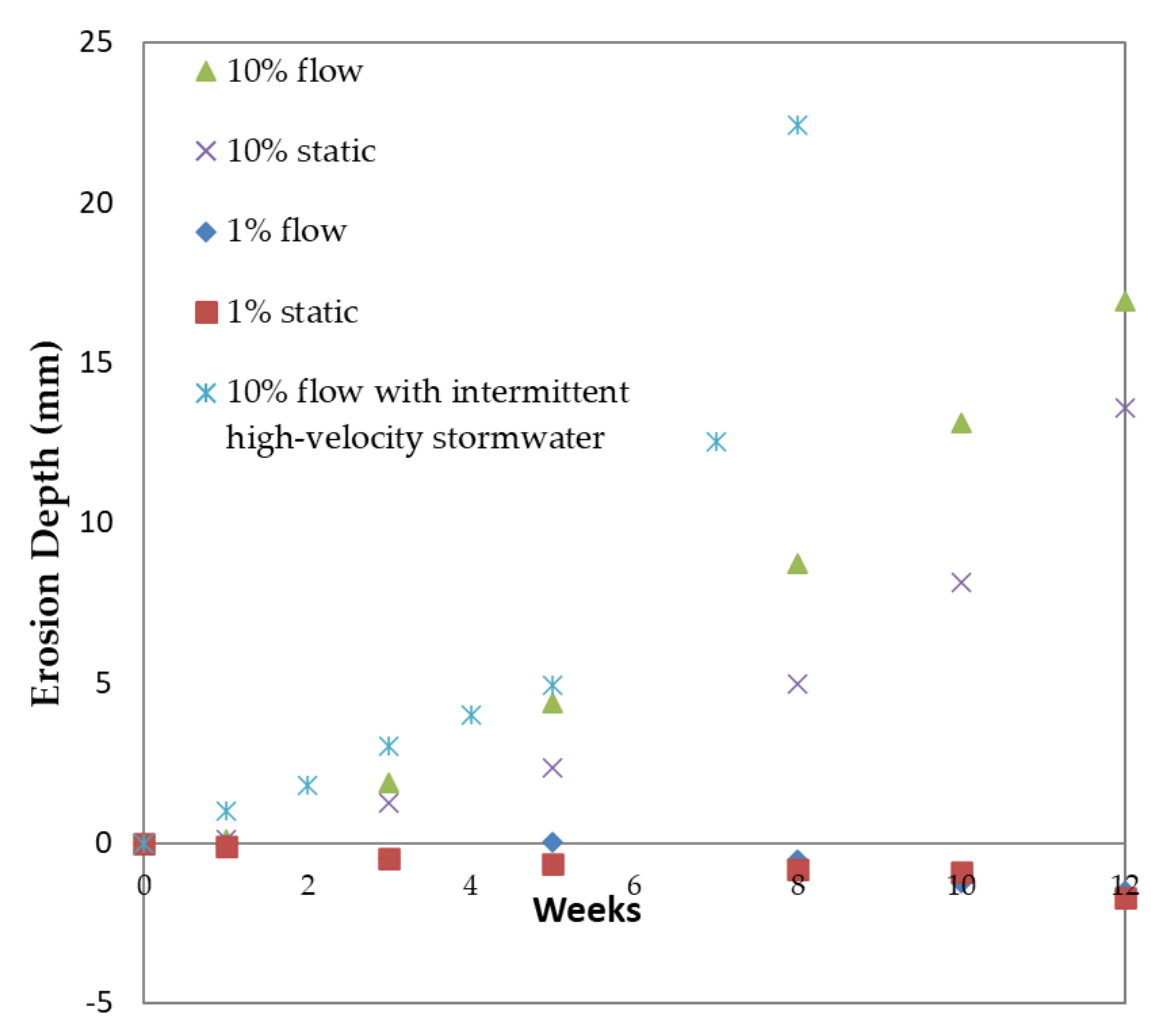

Figure 6. Erosion depth of concrete specimens as a function of time, under static, constant, and intermittent flowrates and $1 \%$ and $10 \% w / w$ acidic solutions.

\subsection{Mechanical Strength}

Concrete specimens before being exposed to an acidic environment had a uniaxial compressive strength (UCS) value of $39 \mathrm{MPa}$ (Figure 7). After 35 days of exposure under $10 \%$ static or flow conditions, strength decrement was $62.5 \%(14.6 \mathrm{MPa})$ and $70 \%(11.5 \mathrm{MPa})$, respectively. After 35 days of exposure, the specimens were disintegrated to a significant extent and could not be utilized for strength tests. It is worth noting that although the specimens lost their strength under flow conditions, the rate of strength loss is almost the same for specimens that have undergone static and flow erodible conditions. This reduction is well represented by a polynomial-type equation. 


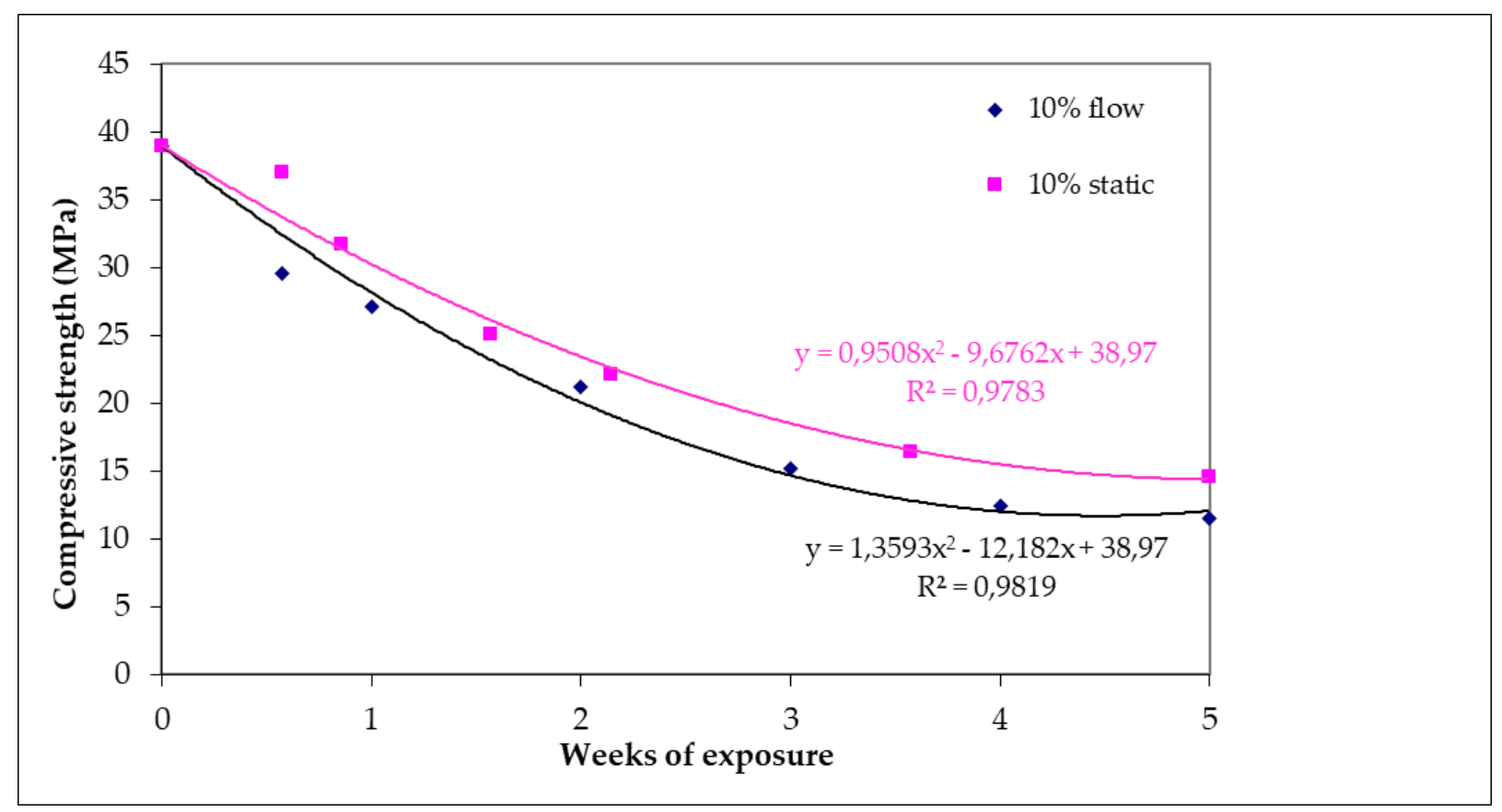

Figure 7. Compressive strength of specimens subjected to $10 \% w / w \mathrm{H}_{2} \mathrm{SO}_{4}$ as a function of day of exposure for static and flow conditions.

Figure 8 shows the reduction of elastic modulus of specimens for both test conditions (static and flow). The value of elastic modulus was $32.8 \mathrm{GPa}$ for the raw specimens. After 35 days of exposure under static or flow conditions, the reduction in the values of elastic modulus appeared to be $46 \%(17.7 \mathrm{GPa})$ and $52 \%$ (15.7 GPa), respectively. In addition, it is observed that under flow conditions, the decrease of elastic modulus is more intense than in static conditions.

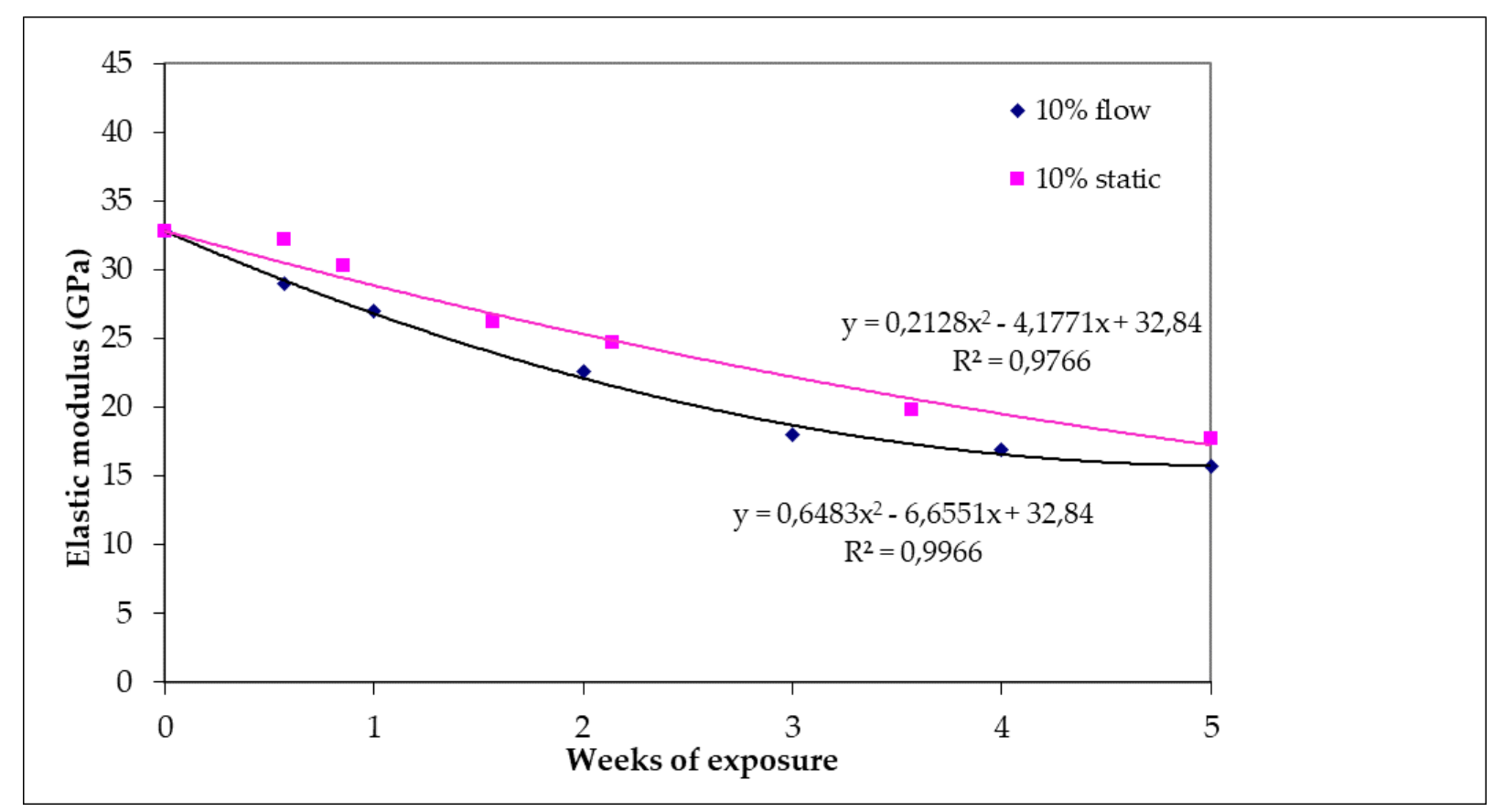

Figure 8. Elastic modulus of specimens subjected to $10 \% w / w \mathrm{H}_{2} \mathrm{SO}_{4}$ as a function of day of exposure for static and flow conditions. 


\section{Discussion}

Gypsum is a corrosion product which forms after the reaction of calcium hydroxide with sulfate. Gypsum formation during sulfuric chemical attack allows fewer sulfate ions to reach the inner part of the concrete. As soon as gypsum is removed during chemical $\mathrm{H}_{2} \mathrm{SO}_{4}$ attack, new concrete surfaces are exposed to acid attack, resulting in progressive deterioration and corrosion rate increase. In the case of biogenic corrosion, the corrosion mechanisms are different. Although few researchers have concluded that the removal of gypsum deposits by wastewater flows can enhance chemical corrosion [11], it should be taken into account that moisture and gypsum can be ideal conditions for biocorrosion to occur. Therefore, under intense conditions of water or wastewater flow that result in the removal of the gypsum layer, the ideal conditions for biocorrosion to occur might be disturbed, resulting in the suppression of the corrosion mechanism. As a result, tests using flowing acidic and wastewater solutions should take place in sewage corrosion studies in order to identify the mechanism under biogenic $\mathrm{H}_{2} \mathrm{~S}$ conditions. In a combined sewer network, high-velocity water flows can remove gypsum deposits from the surface. In the case of chemical sulfuric acid attack, authors showed that this could accelerate the corrosion of concrete.

Under realistic sewer conditions, acid concentration is less than $1 \%$ and it would take years for concrete deterioration to occur. Most research papers regarding deterioration of concrete due to sulfuric acid use much higher concentrations to accelerate the procedure. In a very comprehensive study from Kawai et al. [21], concrete specimens were immersed in sulfuric acid solutions of $\mathrm{pH}=1$ and $\mathrm{pH}=2$ for 1600 days. These conditions are realistic and are the conditions under which most concrete deterioration of actual structures takes place. The findings of Kawai et al. [21] showed expansion of the specimens at the beginning and loss of concrete after some years for most concrete types. Both $1 \%$ and $10 \% \mathrm{H}_{2} \mathrm{SO}_{4}$ concentrations are accelerated cases, and a $5 \% \mathrm{H}_{2} \mathrm{SO}_{4}$ case should fall between the two. As was shown, in the case of $1 \%$, one should increase the experimental time at least by double in order to observe increases in corrosion depth.

Currently, different coatings based on $\mathrm{Mg}(\mathrm{OH})_{2}$ and $\mathrm{MgO}$ are being tested for their performance in concrete corrosion mitigation. In tests with chemical sulfuric acid, it was shown that flowing sulfuric acid accelerated the deterioration [6]. Since stormwater can easily remove the protective layer, the ideal coating should have adhesion additives and should be water resistant, in order to withstand heavy rainfall in a combined sewer network.

For measuring the adhesion strength of coatings on a variety of substrates, pull-off tests can be used. The pull-off adhesion strength and mode of failure of a coating from a concrete substrate are important performance properties that are used in specifications. The ASTM D7234-19 is a standard test method for pull-off adhesion strength of coatings on concrete using portable pull-off adhesion testers, and it serves as a means for uniformly preparing and testing coated surfaces and evaluating and reporting the results [22].

The authors of the current work recommend the conduction of supplementary tests (i.e., in addition to pull-off tests) under high horizontal velocity of the tested solution in order to examine the performance of coatings under rather extreme conditions of water flow (in order to simulate the sewage network performance during a heavy storm incident in a combined sewer system). Common additives, such as cellulose-based additives, can be used to improve the adhesion ability of coatings. Factors to be considered include the ideal concentration of the coatings and their behavior under stormwater flows.

\section{Conclusions}

The chemical $\mathrm{H}_{2} \mathrm{SO}_{4}$ attack on concrete samples was studied. Increasing $\mathrm{H}_{2} \mathrm{SO}_{4}$ concentration led to higher erosion depth. In addition, higher solution flow rate led to faster deterioration. Results show that flow should be taken into account in future tests, since it accelerates concrete corrosion. It was observed that under flow conditions, the decrease of elastic modulus was more intense than in the static ones. This study included tests for concrete corrosion with intermittent flows, since in a combined sewer, intermittent 
flows due to rainfall are more realistic than static effluents. Stormwater in combined sewers could remove the gypsum layer in less than $20 \mathrm{~min}$, thus accelerating the chemical corrosion, but if $\mathrm{H}_{2} \mathrm{SO}_{4}$ is biogenic, the removal of gypsum by stormwater could have a positive effect on corrosion mitigation. Since new coatings are being developed for the protection of concrete surfaces, coating adhesion onto the concrete surface is one of the major factors that should be studied in future research. For combined sewers, selected coatings should withstand the effect of stormwater since high-velocity flows could easily remove coatings without proper adhesion additives. Finally, results from these and similar studies can be used as input data for stochastic corrosion modeling (e.g., [23]) for corrosion prediction and mitigation.

Author Contributions: Conceptualization, G.F. and P.S.; methodology, G.F., P.S., and A.T.; investigation, G.F. and E.P.; data curation, C.A.A.; writing-original draft preparation, G.F. and A.T.; writing-review and editing, C.A.A. and P.S.; supervision, P.S.; project administration, P.S.; funding acquisition, P.S. All authors have read and agreed to the published version of the manuscript.

Funding: This research has been co-financed by the European Union and Greek national funds through the Operational Program Competitiveness, Entrepreneurship and Innovation, under the call RESEARCH-CREATE-INNOVATE (project code: T1EDK-02355-title 'Novel Coating Materials for Corrosion Protection of Sewer Network Pipes').

Institutional Review Board Statement: Not applicable.

Informed Consent Statement: Not applicable.

Data Availability Statement: The data presented in this study are available upon request from the corresponding author.

Conflicts of Interest: The authors declare no conflict of interest.

\section{References}

1. Wiener, M.S.; Salasab, B.; Quintero-Núñez, M.; Zlatev, R. Effect of H2S on corrosion in polluted waters: A review. Corros. Eng. Sci. Technol. 2006, 41, 221-227. [CrossRef]

2. Zhang, L.; De Schryver, P.; De Gusseme, B.; De Muynck, W.; Boon, N.; Verstraete, W. Chemical and biological technologies for hydrogen sulfide emission control in sewer systems: A review. Water Res. 2008, 42, 1-12. [CrossRef] [PubMed]

3. Fytianos, G.; Baltikas, V.; Loukovitis, D.; Banti, D.C.; Sfikas, A.; Papastergiadis, E.; Samaras, P. Biocorrosion of Concrete Sewers in Greece: Current Practices and Challenges. Sustainability 2020, 12, 2638. [CrossRef]

4. Crownmag. Innovative Coating Materials for Corrosion Protection of Sewer Network Pipes. Available online: http://crownmag. gr/en/ (accessed on 14 August 2020).

5. Merachtsaki, D.; Tsardaka, E.-C.; Tsampali, E.; Simeonidis, K.; Anastasiou, E.; Yiannoulakis, H.; Zouboulis, A. Study of Corrosion Protection of Concrete in Sewage Systems with Magnesium Hydroxide Coatings. Environ. Sci. Proc. 2020, 2, 27. [CrossRef]

6. Merachtsaki, D.; Fytianos, G.; Papastergiadis, E.; Samaras, P.; Yiannoulakis, H.; Zouboulis, A. Properties and Performance of Novel $\mathrm{Mg}(\mathrm{OH})_{2}$-Based Coatings for Corrosion Mitigation in Concrete Sewer Pipes. Materials 2020, 13, 5291. [CrossRef] [PubMed]

7. Breysse, D. 3-Deterioration processes in reinforced concrete: An overview. In Woodhead Publishing Series in Civil and Structural Engineering; Maierhofer, C., Reinhardt, H.-W., Dobmann, G., Eds.; Woodhead Publishing: Sawston, UK, 2010; Volume 1, pp. 28-56.

8. Attiogbe, E.K.; Rizkalla, S.H. Response of concrete to sulfuric acid attack. ACI Mater. J. 1988, 85, 481-488.

9. Kawai, K. Deterioration of Concrete Exposed to Flowing Sulfuric Acid Solution. In Proceedings of the 13th International Conference on Civil and Environmental Engineering (ICCEE-2014), Busan, Korea, 23-24 September 2014; p. 10.

10. Ookame, Y.; Hatano, Y.; Kawai, K. Study on Long Term Concrete Deterioration Due to Sulfuric Acid. In Proceedings of the Third International Conference on Sustainable Construction Materials and Technologies, Kyoto, Japan, 18-21 August 2013.

11. Mori, T.; Nonaka, T.; Tazaki, K.; Koga, M.; Hikosaka, Y.; Noda, S. Interactions of nutrients, moisture and pH on microbial corrosion of concrete sewer pipes. Water Res. 1992, 26, 29-37. [CrossRef]

12. Nielsen, A.H.; Hvitved-Jacobsen, T.; Jensen, H.S.; Vollertsen, J. Experimental Evaluation of the Stoichiometry of Sulfide-Related Concrete Sewer Corrosion. J. Environ. Eng. 2014, 140, 04013009. [CrossRef]

13. Monteny, J.; De Belie, N.; Vincke, E.; Verstraete, W.; Taerwe, L. Chemical and microbiological tests to simulate sulfuric acid corrosion of polymer-modified concrete. Cem. Concr. Res. 2001, 31, 1359-1365. [CrossRef]

14. Monteny, J.; Vincke, E.; Beeldens, A.; De Belie, N.; Taerwe, L.; Van Gemert, D.; Verstraete, W. Chemical, microbiological, and in situ test methods for biogenic sulfuric acid corrosion of concrete. Cem. Concr. Res. 2000, 30, 623-634. [CrossRef]

15. Aviam, O.; Bar-Nes, G.; Zeiri, Y.; Sivan, A. Accelerated Biodegradation of Cement by Sulfur-Oxidizing Bacteria as a Bioassay for Evaluating Immobilization of Low-Level Radioactive Waste. Appl. Environ. Microbiol. 2004, 70, 6031-6036. [CrossRef] [PubMed] 
16. Hadja, K.; Kharchi, F. The Erosion of Reinforced Concrete Walls by the Flow of Rainwater. Int. J. Concr. Struct. Mater. 2017, 11, 151-159. [CrossRef]

17. Roghanian, N.; Banthia, N. Development of a sustainable coating and repair material to prevent bio-corrosion in concrete sewer and waste-water pipes. Cem. Concr. Compos. 2019, 100, 99-107. [CrossRef]

18. Portland Cement Association. PCA, Types and Causes of Concrete Deterioration; PCA: Skokie, IL, USA, $2002 ; \mathrm{p} .16$.

19. Design Criteria and Standard Drawings. Available online: https://www.vaughan.ca/services/DesignCriteria/files/Sanitary\%20 Sewerage\%20System.pdf (accessed on 14 August 2020).

20. ASTM. C469/C469M-10 Standard Test Method for Static Modulus of Elasticity and Poisson's Ratio of Concrete in Compression; ASTM Internatiomal: West Conshohocken, PA, USA, 2012.

21. Kawai, K.; Ogawa, Y.; Tsubone, K.; Yamaguchi, Y. Degradation of concrete immersed in sulfuric acid for a long term. Cem. Sci. Concr. Technol. 2017, 70, 397-404. (In Japanease) [CrossRef]

22. ASTM D7234-19. Standard Test Method for Pull-Off Adhesion Strength of Coatings on Concrete Using Portable Pull-off Adhesion Testers; ASTM Internatiomal: West Conshohocken, PA, USA, 2019; Available online: https://www.astm.org/Standards/D7234.htm (accessed on 14 December 2020).

23. Kamiński, M. The Stochastic Perturbation Method for Computational Mechanics; Wiley: Hoboken, NJ, USA, 2013. 